\title{
変性々腰椎疾患における後方手術例の検討
}

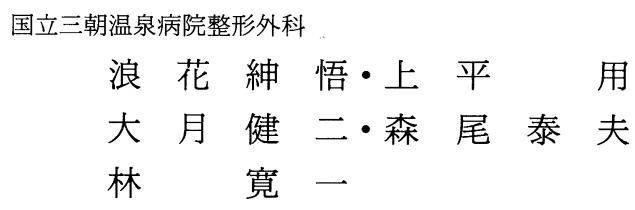

\section{Follow-up Study of Degenerative Lumbar Diseases by Posterior Approach Operation}

by

\section{Shingo Naniwa, Mochiru Kamihira, Kengi Ohtsuki, Yasuo Morio and Kanichi Hayashi}

Department of Orthopedic Surgery, National Misasa Onsen Hospital

328 cases of degenerative lumbar diseases were treated by posterior approach operation for past 11 years. They consisted of lumbar disc herniation (LDH) in 190 cases, lumbar spinal canal stenosis (LCS) in 109, osteochondrosis intervertebralis in 12 and lumbar spondylolysis or olisthesis in 15 . We sent these patients postcards and gathered information by questionaires. 219 postcards $(66.8 \%)$ were returned to us. The results of operative intervention were fair or poor in 11 cases (9\%) of LDH and in 12 cases (16.4\%) of LCS. These fair or poor cases were studied. In LDH, some of patients with severe pain and numbness of legs had sequestrated or large hernia. Patients with low back pain had disc instability and narrowing on X-ray.

In LCS, many patients of fair or poor results had complications or postoperative stenosis. All of 8 patients who had drop foot caused by LDH or LCS have severe numbness of legs.

は じめに

保存的治療に抵抗する頑固な腰痛，下肢痛および神 経脱落症状のある変性々腰椎疾患に対しては手術的療 法が必要となる。術式の選択には，患者の年令，性別， 職業, 合併症, 脊柱管狭窄, 分離の有無, 迄りの程度, 不安定性の存在など多くの因子を総合的に判断した上 で決めなければならない. 過去 11 年間, 後方手術を施 行した症例に対し予後についてアンケート調查を行い, 予後不良例の検討を行った。

\section{対象}

当科にて 1976 年 4 月より 1987 年 3 月までに, 変性久 腰椎疾患に対して施行した後方手術は 328 例, 疾患別 には腰椎々間板へルニア (ヘルニア) 190 例, 腰椎々間
板症（椎間板症） 12 例, 腰椎分離・过り症 $($ 分離・过 り症） 17 例，腰部脊柱管狭窄症（狭窄症）109 例であ つた（表 1 )。

ヘルニア手術法は, Love 法に準じた discectomy が 主体であるが，髄核の摘出ばかりに注目せず，神経根 の可動性が獲得されることに留意し，そのために神経 根管の unroofing を行うことがしばしばある。

最近では,すべての症例に癒着と laminectomy menbrane の防止のため free fat grafting を行っている. また再手術症例や, 術後不安定性の危惧されるものに 後側方固定術（以下 PLF）を併用することもある. ヘルニア高位は $\mathrm{L}_{4 / 5}, \mathrm{~L}_{5} / \mathrm{S}_{1}$ が 186 例と多数を占めて いた（表 2 ）。

椎間板症は狭義の意味で使用しているが，不安定椎 などといわれるものである。ここでは椎間関節症も含 
表 1 変形性腰椎疾患の後方手術 (328例)

(1976. $4 \sim 1987 . \quad 3$ )

\begin{tabular}{|c|c|c|c|c|c|c|c|}
\hline \multirow[b]{2}{*}{ 疾 患 名 } & \multirow{2}{*}{ 手 術 数 } & \multirow{2}{*}{ 手 術 法 } & \multicolumn{3}{|c|}{ 年令 } & \multirow{2}{*}{$\frac{\text { 性 }}{\text { 男 }}$} & \multirow[t]{2}{*}{ 別 } \\
\hline & & & 最 小 & 最高 & 平均 & & \\
\hline 腰椎々間板へルニア & 190 & ラブ法＋(PLF) & 12 才 & 77 才 & 37.3 & 126 例 & 64 例 \\
\hline 腰椎々間板症 & 12 & $\begin{array}{l}\text { 椎弓切除術 } \\
\quad+\text { PLF }\end{array}$ & 20 & 45 & 33.6 & 10 & 2 \\
\hline 腰椎分離 - 过り症 & 17 & $\begin{array}{l}\text { 椎弓切除術 } \\
+\mathrm{PLF}+(\mathrm{SI})\end{array}$ & 16 & 55 & 33.2 & 10 & 7 \\
\hline 腰部脊柱管狭窄症 & 109 & $\begin{array}{c}\text { 椎弓切除術 } \\
+(\mathrm{PLF})+(\mathrm{SI})\end{array}$ & 33 & 81 & 57.3 & 81 & 28 \\
\hline
\end{tabular}

PLF : Posterolateral Fusion

SI : Spinal Instrumentation

表 2 腰椎々間板ヘルニア

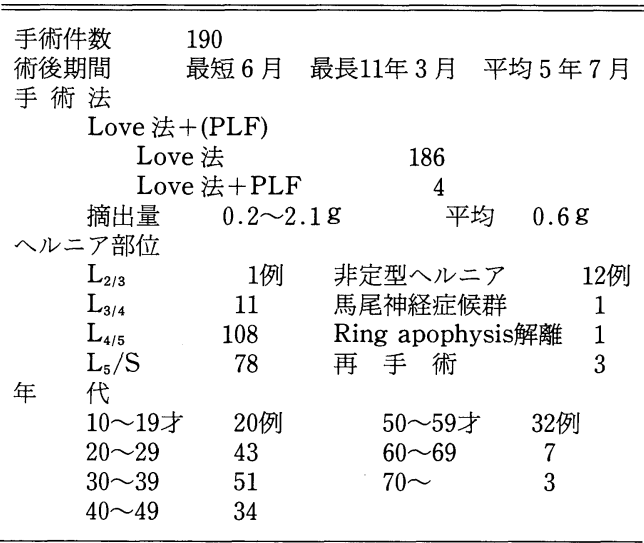

めている.

手術の適応を決定する上で，もつとも難渋する疾患 の一つである.すなわち，不安定性の明らかなものは 論外として, 各種のレ線検査上もほとんど著明な変化 にとぼしく,その上臨床的他覚所見も不明瞭であるが, 頑固な腰痛や下肢痛が持続して日常生活や就労を非常 に困難にしているものである。

椎弓切除を行い椎間板や神経根を十分に検索し，椎 間関節固定術を含めた PLF を行っているが, 術前のレ 線所見で想像していた以上に椎間関節の変性と不安定 性を呈している症例が多かった（表 3 ）。

分離・过り症は，全例固定術を併用し，分離症の 1 例は分離椎弓切除術 (Gill 法) に PLF と spinal instrumentation (Knodt rod)による固定術を施行した。分
表 3 腰椎々間板症

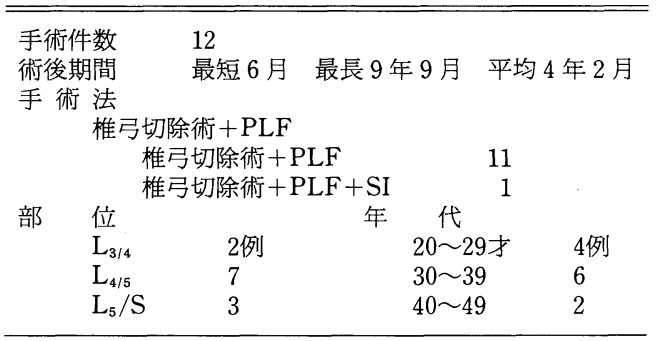

表 4 腰椎分離症

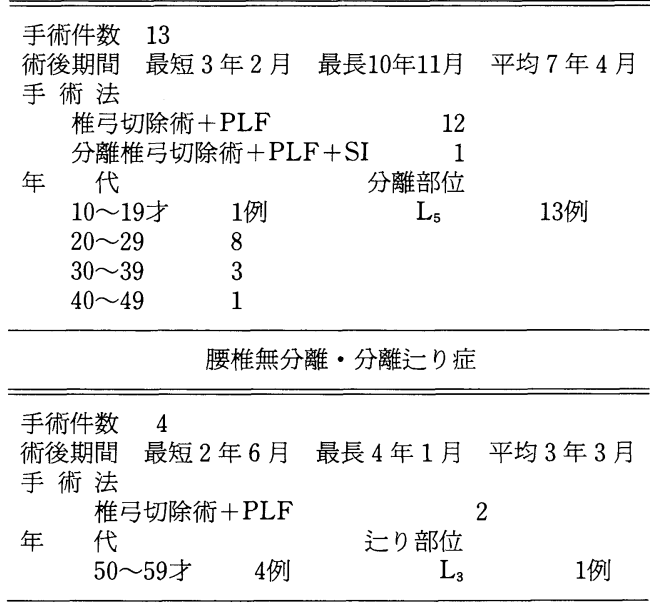

離椎弓そのものの固定術を行ったことはない（表 4 ）. 狭窄症に対しては，当初はなにがなんでも広範囲椎 弓切除術という考え方で手術を進めていたが，現今は 


\section{表 5 腰部脊柱管狭窄症}

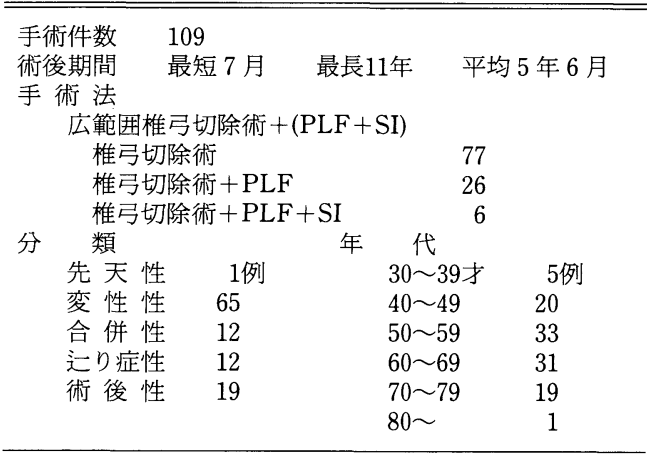

ミエロ, 選択的神経根造影, 根ブロック, CT などの総 合所見により，可及的に責任病巣を追求して，椎弓切 除術の範囲が比較的限局化される傾向にある症例が多 いが，その場合でも外側方への除圧は，内側椎間関節 切除などにより十分行っている. 同時に比較的年令の 若い者や, 術後不安定性の出現が危惧されるものには PLFを行い, 時には spinal instrumentation も併用し ている. 全症例の約 $30 \%$ は固定術を併用していた。 手術時年令は 50 代， 60 代が多く，平均年令 57.3 才と ヘルニアの 37.3 才に比し，高令者が多かった(表 5 ).

手術を施行した 328 例に対し, 葉書による予後調查 を行った，手術に対する満足度を良かった，わからな い，いいえで，腰痛・下肢痛・下肢のシビレをない， ある場合は軽いか, 強いかで, 日常生活の不自由さ, 術前後の職業の変遷について回答をお願いした。

\section{結果}

回答率は全体で 328 例中 219 例, $66.8 \%$ と 3 分の 2 以上の回答を得た（表 6 ）.

満足度においては, 良かったと答えた症例が 60 〜 80 \%あった，椎間板症ではやや低い結果であった。しか し，それぞれの疾患でいいえと答えた不満足例も数例 ずつあった。 わからないと答えた症例も不満足例とし ている.

日常生活制限・腰痛・下肢痛・下肢のシビレの項目 について強いと答えた症例が, それぞれの疾患で 10～20 \%ずつあった（表 7 ).

以上の結果を Macnab に準ずる判定基準にあてはめ 4 段階に分類すると, 可・不可を含める術後結果不良 例は, ヘルニアで 8.9 , 椎間板症 $12.5 \%$, 分離, 过り 症 $20 \%$ であった（表 8 ）.
表 6 術後成績 (1)

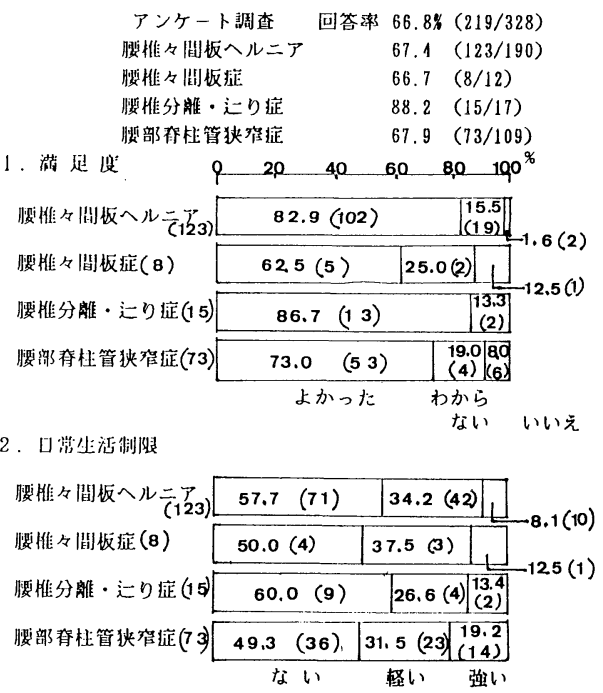

表 7 術後成績（2）

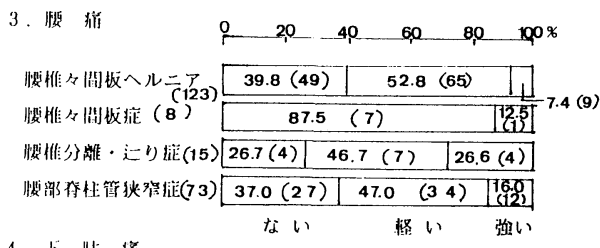

1.下忮福

\begin{tabular}{|c|c|c|}
\hline 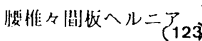 & $65,0(80)$ & $30.0(37)$ \\
\hline 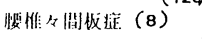 & $37.5(3)$ & $37.5(3)$ \\
\hline 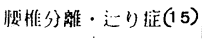 & 66.7 (4) & $26.6(4)$ \\
\hline 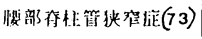 & $51.0 \quad(37)$ & $37.0 \quad(27)]_{[2.0}^{[2.0}$ \\
\hline
\end{tabular}

5.ト肢のしびれ

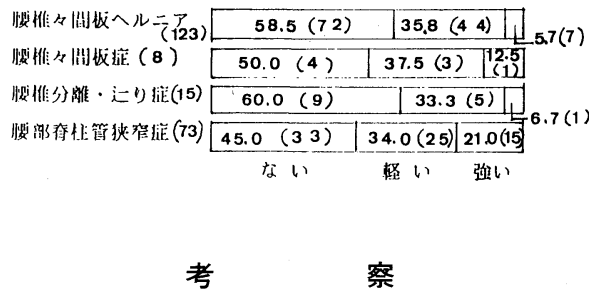

以上のアンケート結果をもとに，大多数を占める， 腰椎々間板へルニア, 腰部脊柱管狭窄症に対し, 予後 不良因子を検討した。

アンケート結果より，満足度において，いいえある いはわからない, および, 日常生活制限, 腰痛, 下肢 痛，下肢のしびれいずれか一つでも強いと答えた症例 
表 8 総合判定

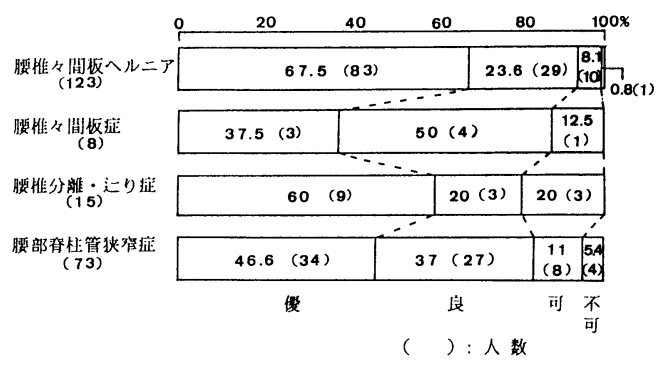

を予後不良例として選びだすと, ヘルニアでは 28 例, 狭窄症では 29 例あり,これらについて retrospectiveに 検討を加えた。

ヘルニアでは下肢痛の強く残存する症例は 6 例あり， このなかに不満足と答えた 2 例が含まれる。術中所見 と対比すると, 遊離へルニアが神経根と強く瘺着した 3 例，下垂足をひきおこすほどへルニアが 2 つの神経 根を強く圧迫した 1 例, 通常の突出へルニア（摘出へ ルニア $0.2 \mathrm{gr}$ ), 術前ヘルニアと診断するも術中ヘルニ アはなく, lateral recessesで神経根を圧迫していた superior facet synd. の各々 1 例あった. よって術中所 見によると, 神経根への圧迫の強い症例で, 調查時ま で強い下肢痛が存在することが多い.

下肢のシビレが強く残存する症例は 7 例あり，その うち 3 例は先述の下肢痛が強く残存する 6 例のなかの 3 例, 術前より下垂足を合併していた 2 例, 遊離へル ニア 1 例と通常の突出ヘルニア 1 例であった. 下肢の シビレも神経根への圧迫の強い症例で強く残存してい る.

腰痛が強く残存する症例は 9 例あり, 術後のレ線所 見より検討すると, 罹患椎間板レベルで著明な狭小化 を 3 例に, 軽度狭小化 3 例, 不安定性を 3 例に認め,
術後椎間板性の疼痛の存在を示唆している.

28 例の術後予後不良例中, 軽い腰痛のみで下肢痛・ シビレともないが, 満足度はわからないと答えた症例 が 7 例あった。これらは術後レ線で罹患椎間板の狭小 化，不安定性を認め，また退院後の外来受診回数の少 ない症例が多い. 術後,このようなレ線変化が見られ る場合，手術により根性坐骨神経痛が消失した後の腰 痛に対する指導と, 入院中も含めて退院後の患者との 接触の重要性を痛感した。

狭窄症における 6 例の不満足例を表 9 に示す.腰痛・ 下肢痛・下肢のシビレとも強い症例が多いが，なかに は疼痛・シビレはないか軽い症例もあった。施行した 手術は広範椎弓切除と半数に固定術を併用していた。 術中所見では除圧後全例において硬膜の拍動は出現し なかったが，これのみで予後の判定は不可能であると 思われる，満足度不良に関連する因子として，椎弓切 除範囲不足を疑わせる症例, 術後性狭窄症で手術操作 の煩雑であった症例の他に，手術以外の胃切除後体力 低下，労災保険患者などの因子の関与も考えられる。

そこで予後不良に関連する合併症について検討する と, 股・膝関節の著明な O. A., 片麻痺, 顼椎 OPLL, 腰椎 OYL の進行, 軟骨発育不全症各々 1 例, 下垂足を 合併した 5 例, 術後性狭窄症 6 例と, 予後不良 29 例中 16 例に以上のものが合併しており, 高令者の多い狭窄 症に対する治療のむずかしさを示している.

椎弓切除に固定術を併用する効果に関して，予後不 良例 29 例中 8 例 $(28 \%$ ) に固定術を併用，それに対し 予後良好例で固定術を併用した症例は 44 例中 10 例 （23％）と単純な比率のみでは固定術の有効性は明ら かではない.しかし，患者の年令，職業，不安定性汇 りの程度によって構築学的に安定性を得る固定術の併 用が有効であった症例も多い.

満足度「いいえ」の 6 症例

表 9 腰部脊柱管狭窄症手術症例における予後不良例

\begin{tabular}{|c|c|c|c|c|c|c|c|}
\hline \multirow{2}{*}{ 年齢 } & \multirow{2}{*}{ 性 } & \multicolumn{3}{|c|}{ アンケート結果 } & \multicolumn{2}{|c|}{ 手術 } & \multirow{2}{*}{ 満足度不良に関連する因子 } \\
\hline & & 腰 & 下肢痛 & シビレ & 固定の併用 & 除圧後硬膜拍動 & \\
\hline 1. 54才 & 男 & $x$ & $x$ & 0 & 無 & 無 & 術後性狭窄症, 頝椎 OPLL \\
\hline 2. 58才 & 男 & $x$ & $x$ & $x$ & 有 & 無 & L4 圧迫骨折後，労災保険 \\
\hline 3. 59才 & 男 & $x$ & $x$ & $x$ & 無 & 無 & 椎弓切除 (L4-5) 範囲不足 \\
\hline 4. 53才 & 女 & $\triangle$ & $\triangle$ & $\triangle$ & 有 & 無 & $(-)$ \\
\hline 5.77才 & 男 & $\triangle$ & 0 & 0 & 無 & 無 & 胃切除後体力低下 \\
\hline 6. 55才 & 男 & $x$ & $x$ & $x$ & 有 & 無 & 術後性 狭窄症 \\
\hline
\end{tabular}

$(x:$ 強い, $\triangle:$ 軽い, $\bigcirc:$ ない $)$ 
・8 例 アンケート返事あり

- 3 例 ॥ な

表 10 下垂足合併症例（11例）

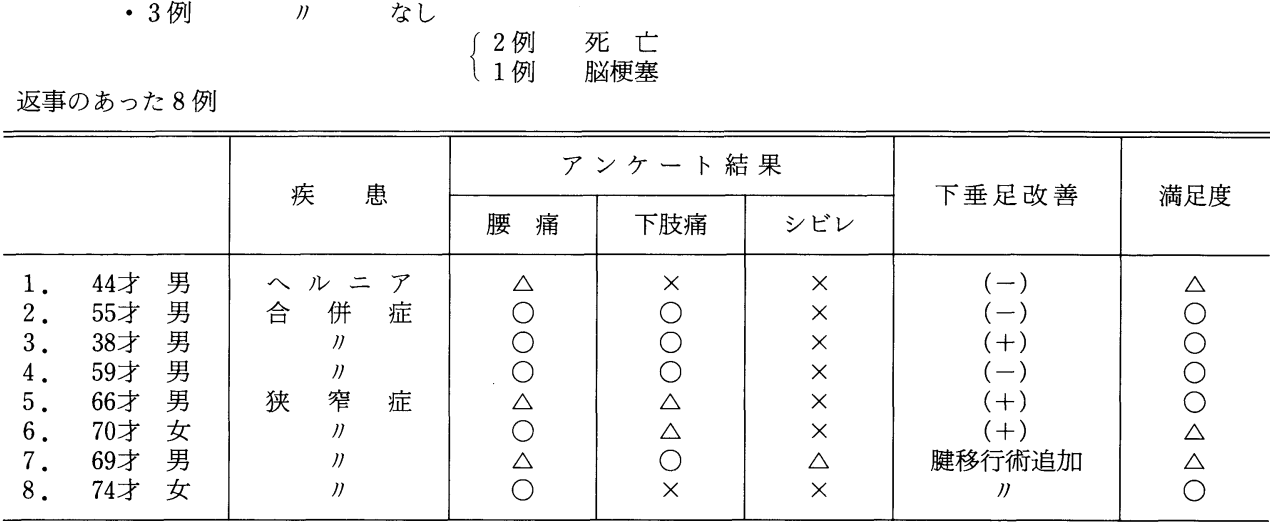

$(\bigcirc:$ ない, $\triangle:$ 軽い, $\times:$ 強い $) ／$ 良かった わからない

ヘルニア，狭窄症により下垂足をきたした 8 例を表 10 に示す．腰痛，下肢痛はないか軽いが，全例に強い 下肢のシビレが残存している。しかし満足度において は比較的満足症例が多い.

\section{ま と め}

1. 当科にて過去 11 年間に, 変性々腰椎疾患に対し て施行した後方手術は 328 例(腰椎椎間板へルニア 190 例, 腰椎々間板症 12 例, 腰椎分離, 过り症 15 例, 腰 部脊柱管狭窄症 109 例) であった。

2. アンケートによる予後調查を行い, 解答率は 66.8 \%（328 例中 219 例）であった.

3. 術後成績において, 可と不可を含めた不良例は, 腰椎々間板へルニア $9 \%$, 腰部脊柱管狭窄症 $16.4 \%$ あった。

4. アンケート結果をもとに予後不良例について検 討した。

・腰椎々間板へルニア：神経根への圧迫の強い症例 で下肢痛，下肢のシビレが強く残存する、レ線上椎間 板変性の所見が見られる症例で腰痛が残存する.

- 腰部脊柱管狭窄症：不満足症例の明らかな原因は 不明. 予後不良例に合併症あるいは，術後性狭窄が多 い. 固定術の併用効果は有意差なし.

・下垂足合併症例は, 全例強い下肢シビレ感残存.

5. 今回, アンケート結果をもとに検討を行ったが,
アンケートの性質上客観性に欠ける点はあるが，手術 の効果は満足度が重要であると思われる。これは手術 手技の向上と共に，医者と患者の信頼関係に大きく左 右される印象をうけた。

\section{参 考 文 献}

1) Macnab, I. : Negative disc exploration. J. B. J.S. 53-A : 891-903, 1971

2）森尾泰夫・他：下垂足を主徵とした腰部脊柱管狭窄 症。中部整災誌，29：1979-1980，1986。

3）大月健二 ・他：腰椎疾患の観血的療法の検討. 医療, $34: 613-618,1980$.

質 問長崎市民病院 江川 正

脊椎管狭窄症の場合，術式もさることながら多椎間 性の症例では, どこまで OPするか問題であるが, 少な くともミエロ上 redundant nerve の像が見られるレベ ルは OP した方がいいのではないかと最近考えているが, 如何ですか.

\section{解 答国立三朝温泉病院 浪花 紳悟} 以前は, 広範囲椎弓切除に固執するも, 最近は, 種々 の検查を総合的に判断し，比較的椎弓切除の範囲を縮 少する傾向にあります. しかし外側方への除圧は必要 十分に行っております。 